$1-1-2015$

\title{
An International Human Right to Self-Sufficiency
}

Haley Palfreyman Jankowski

Follow this and additional works at: https://scholarlycommons.law.emory.edu/eilr-recent-developments

\section{Recommended Citation}

Haley P. Jankowski, An International Human Right to Self-Sufficiency, 29 Emory Int'l L. Rev. Recent Dev. 2039 (2015).

Available at: https://scholarlycommons.law.emory.edu/eilr-recent-developments/25

This Essay is brought to you for free and open access by the Journals at Emory Law Scholarly Commons. It has been accepted for inclusion in Emory International Law Review Recent Developments by an authorized administrator of Emory Law Scholarly Commons. For more information, please contact law-scholarlycommons@emory.edu. 


\title{
AN INTERNATIONAL HUMAN RIGHT TO SELF- SUFFICIENCY
}

\author{
Haley Palfreyman Jankowski ${ }^{*}$
}

\begin{abstract}
With the recent onslaught of global natural disasters and terrorism attacks, all people should be preparing themselves. To allow for this necessary preparation, the world community should recognize an international human right of all people to live in an environment of self-sufficiency. International law scholars have recognized similar rights and have often mentioned the importance of self-sufficiency in the context of these other rights, but none have yet cited self-sufficiency as an independent right. This article argues that such a right is inherent to every individual and is a natural outgrowth of several basic recognized human rights.

This article examines portions of several international treaties and documents to show textual support for why self-sufficiency should be recognized as an emerging international right. Next, it explores recent scholarship, current events, and social movements to show a contemporary will for the recognition of a right to self-sufficiency. Finally, this article concludes by contending that the international community should recognize the emerging right of individuals to create and maintain their own self-sufficient environments, and by arguing that state governments have an affirmative duty not only to avoid violating this right, but also to ensure its fulfillment.
\end{abstract}

* Law Clerk, United States Court of Appeals for the Ninth Circuit. J.D. April 2014, J. Reuben Clark Law School, Brigham Young University. Ms. Jankowski thanks Professor Eric Jensen for the guidance and revisions he provided in the preparation of this Article, and, as always, she thanks her family for their love and support. 


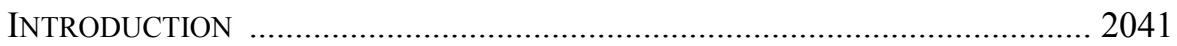

I. AN EMERGING Right to SELF-SUfFICIENCY: LEGAL EXISTENCE ... 2045

A. Recognized Rights Similar to Self-Sufficiency ........................ 2047

B. Social Movements Showing a Self-Sufficiency Trend .............. 2051

II. Why We NeEd to Formally Recognize a Right to Self-

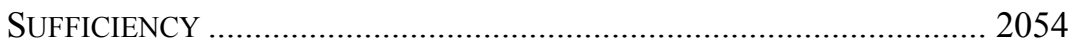

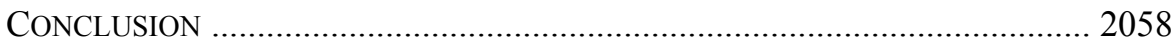

Give a man a fish and he will eat for a day. Teach a man to fish and he will eat for the rest of his life.

—Chinese Proverb ${ }^{1}$

\section{INTRODUCTION}

On the morning of November 8, 2013, Typhoon Haiyan tore through the Philippines with winds whipping at 195 miles per hour, ultimately taking more than 6000 lives. $^{2}$ In the aftermath of the catastrophe, reports of nationwide devastation and desperation surfaced daily. ${ }^{3}$ For example, one morning, five days after disaster struck, a mob killed several Filipino civilians who were merely trying to obtain food from a rice warehouse. ${ }^{4}$ Even if international aid really was on its way to these people, news of such imminent aid may not provide much comfort because "[t]hirst and starvation [do not] wait for help to arrive." $"$ The dire aftermath in the Philippines teaches a vital lesson: the smartest life decision people can make is to invest in self-sufficient preparation because the government will not be able to save them. ${ }^{6}$ Self-sufficiency has a vital capacity to save lives in times of scarcity and to sustain life in times of plenty, and it should be recognized as an international human right.

1 OXFORD DiCTIONARY OF QUOTATIONS 684 (7th ed. 2009).

2 Cris Larano, World News: Typhoon Haiyan Deaths Top 6,000, Wall St. J., Aug. 20, 2013, at A8; F. Brinley Bruton, Typhoon Haiyan: World Bank Offers \$500M Loan to Philippines as Aid Logjams Persist, NBC News (Nov. 18, 2013), http://worldnews.nbcnews.com/_news/2013/11/18/21515801-typhoon-haiyanworld-bank-offers-500m-loan-to-philippines-as-aid-logjams-persist.

3 Matt Gurney, Lesson from the Philippines: The Government Won't Save You, NATIONAL PosT (Nov. 13, 2013), http://fullcomment.nationalpost.com/2013/11/13/matt-gurney-lesson-from-the-philippinesthe-government-wont-save-you/.

4 Kristen Gelineau \& Jim Gomez, Philippines Typhoon Disaster Zone Feared Descending into Chaos as People Killed After Mobs Overrun Rice Warehouse, NATIONAL POST (Nov. 13, 2013), http://news. nationalpost.com/2013/11/13/philippines-typhoon-disaster-zone-feared-descending-into-chaos-as-peoplekilled-after-mobs-overrun-rice-warehouse/.

5 Gurney, supra note 3.

6 See id. 
International agreements and treaties have recognized several international human rights, ${ }^{7}$ but no one has ever answered the question of whether a human right to self-sufficiency exists. This article explores international documents and treaties to recognize the emerging international human right to selfsufficiency. For the purposes of this article, self-sufficiency is defined as the ability "to maintain oneself or itself without outside aid" or the "capab[ility] of providing for one's own needs [a farm].",

This Article concludes that all people should have the right to create and maintain a self-sufficient atmosphere, which they can use to support themselves without depending on outside aid, and state governments have a duty to not only avoid infringing on this right, but also to take action to protect it. For example, all people would have a right to collect seventy-two hour kits, store sufficient water and food, maintain a farm or garden, and raise agriculture. No government should be able to unreasonably inhibit people from taking these self-sufficient measures. Rather, state governments should act to protect this right.

The right to self-sufficiency is determined based on a cost-benefit analysis and a reasonable person standard; for a more detailed explanation of this right and its full contours, see my forthcoming Article: A Human Right to SelfSufficiency: Meaning and Contours. ${ }^{9}$ The scope of this Article merely covers the question of whether a right to an environment of self-sufficiency exists in international human rights law, and it argues that self-sufficiency is an

7 See generally, International Covenant on Civil and Political Rights, Dec. 19, 1966, 999 U.N.T.S. 171 [hereinafter "ICCPR"]; International Covenant on Economic, Social, and Cultural Rights, Dec. 16, 1966, 993 U.N.T.S. 3 [hereinafter "ICESCR"].

8 MERriam-Webster's Collegiate Dictionary 1129 (11th ed. 2007) (defining "self-sufficient); see also Self-sufficient, GOOGLE, https://www.google.com/search?q=self-sufficiency+definition\&oq=selfsufficiency+definition\&aqs=chrome..69i57j69i6015\&sourceid $=$ chrome\&ie=UTF-8\#q=self-sufficient + definition (last visited Nov. 15, 2014) (adding to Merriam-Webster's self-sufficient definition: "needing no outside help in satisfying one's basic needs, especially with regard to the production of food" and, by implication, water). International authorities have defined self-sufficiency similarly; see Press Release, General Assembly, Holistic Approach Critical in Addressing Impact of Climate Change on Agriculture: Delegates Say, as Second Committee Takes Up Food Security, Nutrition, U.N. Press Release GA/EF/3377 (Oct. 28, 2013), available at http://www.un.org/News/Press/docs/2013/gaef3377.doc.htm (discussing a country's self-sufficiency goal in the context of food and stating that the nation had "achieved the goal of selfsufficiency in rice, making it secure in a staple food."); see generally Side Event Draft Concept Note, A Response to the World Food Crisis: Smallholder Agriculture, Food Security and Rural Development in Africa, U.N. Africa's Development Needs Side Event Draft Concept Note (Sept. 22, 2008) (on file with the United Nations), http://www.un.org/ga/president/62/ThematicDebates/adn/AResponsetotheWorldFoodCrisis.

9 The Author is presently researching and intends to publish A Human Right to Self-Sufficiency: Meaning and Contours. 
emerging right that should be recognized by the international community. This is an affirmative right, meaning state governments have a positive duty to work toward its fulfillment.

Looking at international human rights law more broadly, many of the currently acknowledged international human rights have been thoroughly researched, documented, and applied by various international law scholars. ${ }^{10}$ Some examples of these rights are included in the International Covenant on Civil and Political Rights (ICCPR). ${ }^{11}$ The ICCPR recognizes many universal and inalienable human rights, including: the right to "self-determination"-to "freely determine [one's] political status and freely pursue [one's] economic, social and cultural development" and security of person," "the right when lawfully within a state "to liberty of movement and freedom to choose his residence," 15 and "the right to freedom of thought, conscience and religion." 16 Also, the International Covenant on Economic, Social and Cultural Rights (ICESCR) ${ }^{17}$ recognizes various human rights, such as: the right to "self-determination," "the right to work," right "to social security, including social insurance,, 20 the right to "an adequate standard of living,"21 the right to an "education,",22 and the right "[t]o take part in cultural life." ${ }^{23}$ Although ICESCR rights are more internationally contested than the civil and political rights recognized in the ICCPR, ${ }^{24}$ as of December 2013, out of about 190 states in the world, ${ }^{25} 162$ states have ratified the

10 See infra Part I.

11 ICCPR, supra note 7.

$12 I d$. at 173.

$13 I d$. at 174.

14 Id. at 175.

$15 I d$. at 176.

16 Id. at 178.

17 ICESCR, supra note 7.

18 Id. at 5.

19 Id. The treaty also recognizes the right to "just and favourable conditions of work," including "[f]air wages," "[s]afe and healthy working conditions," and "reasonable limitation of working hours." Id. at 6.

20 Id. at 7.

21 Id.

22 Id. at 8

23 Id. at 9.

24 Christian Tomuschat, International Covenant on Civil and Political Rights 1 (2008), http://legal.un.org/avl/pdf/ha/iccpr/iccpr_e.pdf.

25 For a more detailed discussion of the elusive "total" number of independent states in the world, see How Many Countries?, WORLD ATLAS, http://www.worldatlas.com/nations.htm (last visited Nov. 15, 2014). 
ICESCR. ${ }^{26}$ So despite the conflict, a significant segment of the international community, more than eighty-five percent of the independent nations in the world, recognizes and is implementing the positive rights listed in the ICESCR. $^{27}$

The right to self-sufficiency is more like the ICESCR rights than the ICCPR rights in that it is a positive right that state governments have the duty to establish. But it is distinguishable from current rights expressly labeled in international treaties because it has only been included impliedly in these treaties and other international documents and never stated as a right itself. Also, self-sufficiency, once broadly recognized, will probably be more easily accepted than many of the ICESCR rights because the government need only enable the development of the right to self-sufficiency, rather than provide everything necessary for the self-sufficiency of its citizens.

Various phrases in past treaties, recent developments in human rights law, and the rising need for the new/emerging right's recognition lead to the conclusion that there is an emerging international human right to selfsufficiency. ${ }^{28}$ All people have a right to live in a community where they are free to take whatever steps they feel necessary in order to thrive in a selfsufficient manner if they chose to, especially in times of need, and state governments worldwide have the duty to create the atmosphere where selfsufficiency can flourish.

The remainder of this article is organized as follows: Part I establishes a brief background of international human rights scholarship to show that while very similar rights have been widely recognized, they are distinguishable from the right to self-sufficiency; this part also examines several international treaties and conventions, such as the Universal Declaration of Human Rights ${ }^{29}$ and the two treaties that emanate from it: the ICCPR and ICESCR, to identify the roots of the right to self-sufficiency and show that it is an emerging human right. ${ }^{30}$ Part II looks to recent scholarship and current events to show a growing

\footnotetext{
26 Chapter IV Human Rights: International Covenant on Economic, Social and Cultural Rights, UNITED NAtions TREAty Collection Databases, http://treaties.un.org/Pages/ViewDetails.aspx?chapter=4\&lang= en\&mtdsg_no=IV-3\&src=TREATY (last visited Nov. 15, 2014).

27 See id.

28 See supra text accompanying notes 11-23; infra Part II.

29 Universal Declaration of Human Rights, G.A. Res. 217 (III) A, U.N. Doc. A/RES/217(III) (Dec. 10, 1948).

30 See infra Part I.
} 
need for the recognition of this right, and it explains why such recognition is so necessary for the international community. ${ }^{31}$

Thus, though currently on the fringes and in the developmental stage, this article argues that the emerging right to self-sufficiency deserves and demands support from the international community.

\section{AN EMERGING Right to SELF-SUfFICIENCY: LEGAL EXISTENCE}

International scholars have discussed several, well-recognized human rights at length, such as the right to self-determination ${ }^{32}$ and the right to work. ${ }^{33}$ And while many have implicitly alluded to a right to self-sufficiency, none have explicitly acknowledged a human right to live in a self-sufficient environment. Scholars occasionally mention the goal of self-sufficiency in the context of the worldwide fight against domestic violence ${ }^{34}$ or against world hunger, ${ }^{35}$ or they

31 See infra Part II.

32 See, e.g., Robert Araujo, Sovereignty, Human Rights, and Self-Determination: The Meaning of International Law, 24 FORDHAM INT'L L.J. 1477, 1477 (2001) (arguing that international human rights are best protected by strengthening and developing the individual state governments); Jerome Wilson, Ethnic Groups and the Right to Self-Determination, 11 CONN. J. INT'L L. 433, 485 (1996) (discussing the right to selfdetermination in the context of recognizing the independence of developing secessionist countries - "if selfdetermination does not extend beyond colonialism, self-determination is in danger of losing its relevance as a principle of international law" (quoting Deborah Z. Cass, Re-Thinking Self-Determination: A Critical Analysis of Current International Law Theories, 18 SYRACUSE J. INT'L L. \& COM. 21, 40 (1992)) (internal quotation marks omitted)); Michael Kirby, Human Rights and Bioethics: The Universal Declaration of Human Rights and UNESCO Universal Declaration of Bioethics and Human Rights, 25 J. CONTEMP. HeALTH L. \& PoL'Y 309, 324 (2009) (The concept of human dignity can, at times, "“encourage a form of paternalism, incompatible with the very spirit of self-determination' that lies at the heart of international human rights." (emphasis added) (quoting G.P. Smith, II, Human Rights and Bioethics, 38 VAND. J. TRANSNAT'L L. 1295, 1312 (2005)).

33 See, e.g., Barbara Stark, At Last? Ratification of the Economic Covenant As A CongressionalExecutive Agreement, 20 TranSNAT'L L. \& CONTEMP. ProbS. 107, 116 (2011) ("In contrast to the general provisions, Articles 6-15 focus on substantive rights. Articles 6, 7, and 8 address the right to work. As the commentary to the Guidelines notes, 'The right to work is of fundamental importance, not only for its own sake but because it can be the key to the enjoyment of many other rights."'); Nsongurua J. Udombana, Social Rights Are Human Rights: Actualizing the Rights to Work and Social Security in Africa, 39 CORNELL INT'L L.J. 181, 189 (2006) ("The ICESCR extends the right to work to include "the right of everyone to the opportunity to gain his living by work which he freely chooses or accepts."'); Gillian MacNaughton \& Diane F. Frey, Decent Work for All: A Holistic Human Rights Approach, 26 AM. U. INT'L L. REV. 441, 456-58 (2011).

34 E.g., Christina Misner-Pollard, Domestic Violence in Russia: Is Current Law Meeting the Needs of Victims and the Obligations of Human Rights Instruments?, 3 ColuM. J. E. EuR. L. 145, 147 (2009) ("Most often, victims successfully leave their abusive partners not due to laws that criminalize domestic violence, but with the help of social programs that aid them in becoming self-sufficient and independent."); Arizona Lawyers Battle Domestic Violence, 38 ARIZ. ATT'Y Oct. 2001, at 45, 45. (discussing the international human rights of bodily integrity, security of person, and adequate standard of living, physical and mental health, and freedom from torture, nondiscrimination and equal protection: " $[\mathrm{t}] \mathrm{o}$ tackle this problem, we must create 
argue that a state can violate international human rights norms by eradicating a state's or community's formerly self-sufficient livelihood. ${ }^{36}$ Some have mentioned that self-sufficiency is an important ideal to achieve for societies at large. ${ }^{37}$ In fact, authors have labeled self-sufficiency the overall goal that international human rights laws are meant to ultimately achieve for all states. ${ }^{38}$ But other than using self-sufficiency as a rationale to support the existence of other human rights and impliedly asserting its vitality, no scholars have yet argued unequivocally for the independent existence of a right to selfsufficiency.

This section recognizes international human rights and social movements that are similar to the right to self-sufficiency-like the right to selfdetermination and the right to work. The increasing recognition of such rights shows that self-sufficiency fits in easily among these existing rights, and it should be recognized for many of the same reasons that justify their

programs aimed at stopping the cycle of intergenerational violence. By helping battered mothers become safe and self-sufficient, these mothers can provide a safer environment for their children"); see also Kenneth Roth, Domestic Violence as an International Human Rights Issue, in HUMAN RigHTS OF WOMEN: NATIONAL AND InTERNATIONAL PERSPECTIVES 326 (Rebecca J. Cook ed., 1994).

35 See, e.g., Laura Niada, Hunger and International Law: The Far-Reaching Scope of the Human Right to Food, 22 CONN. J. INT'L L. 131, 139 (2006) (discussing self-sufficiency in the context of world hunger and arguing that international law has a role in facilitating the right to food embodied in the ICESCR but that selfsufficiency does not guarantee food security: "[w]ith regard to trade, food self-sufficiency is hardly an indicator of food security. Indeed, some countries engaging in self-sufficiency are vulnerable to domestic surpluses and deficits, while many countries that are not self-sufficient do not suffer from serious food shortages").

36 See, e.g., Todd Howland, U.S. Law As A Tool of Forced Social Change: A Contextual Examination of the Human Rights Violations by the United States Government Against Native Americans at Big Mountain, 7 B.C. THIRD WORLD L. J. 61, 70 (1987) (arguing that the United States violated international human rights norms in its treatment of the Native Americans: "[ $t$ ]he Native Americans have been forced into an economic situation under which their self-sufficient ways were destroyed to the point that their economy must be supported by the government"); see also Richard D. Garcia \& Todd Howland, Determining the Legitimacy of Spanish Land Grants in Colorado: Conflicting Values, Legal Pluralism, and Demystification of the Sangre De Cristo/Rael Case, 16 CHICANO-LATINO L. REV. 39, 68 (1995) (arguing that international human rights norms bar states from depriving a people "of its own means of subsistence" (quoting Article 1 of the ICCPR)).

37 See, e.g., Garcia \& Howland, supra note 36, at 68 ("Therefore, to avoid irreparable harm to the development of a people and to their economic productivity and self-sufficiency, United States courts must seriously consider other legal principles which are implicated in the Rael case."). While Garcia and Howland recognize that people have a right not to be deprived of their livelihood and culture, and further recognize that attaining a status of self-sufficiency makes up a component of this goal, they do not take the argument one step further and say that self-sufficiency should be an international human right. Id.

38 See, e.g., Mary AnN Glendon, Rights TALK: The Impoverishment of Political Discourse 14 (1991) (stating that human rights law is characterized by "excessive homage to individual independence and self-sufficiency, [and] its habitual concentration on the individual and the state at the expense of the intermediate groups of civil society"). 
recognition. But also, self-sufficiency is significantly different from such recognized rights to warrant and necessitate its independent recognition.

Furthermore, analysis of these pre-existing rights and the specific texts of international treaties and covenants provides persuasive evidence of how selfsufficiency itself is emerging as an international human right. International treaties and covenants that have been written, signed, and ratified over the years and their accompanying legislative histories all establish roots for the recognition of a right to live in an environment that encourages or at least allows self-sufficient living. Additionally, current social movements show an international trend toward the right to an environment of self-sufficiency. Thus, self-sufficiency is at least emerging as a legal right on the international playing field.

\section{A. Recognized Rights Similar to Self-Sufficiency}

At least a few of the roots and rationales behind the right to self-sufficiency are embedded in several rights that are already widely recognized in international law, but self-sufficiency is different enough that it merits its own, independent status as an emerging international human right. Some such rights that bare a resemblance include the right of self-determination, right to work, ${ }^{39}$ and the right to an adequate standard of living. ${ }^{40}$ This section discusses several of these rights and distinguishes them from the right to an environment of selfsufficiency.

Both the ICESCR and the ICCPR recognize the right of selfdetermination. ${ }^{41}$ This right means that people may "freely determine their political status and freely pursue their economic, social and cultural development." 42 States are generally under an obligation to allow their citizens the right to self-determination, whether they have signed and ratified the ICESCR and ICCPR or not." This means "[s]tates must refrain from

\footnotetext{
39 See ICESCR, supra note 7, at 5-6.

40 See id. at 7.

41 Id. at 5; ICCPR, supra note 7, at 173.

42 ICESCR, supra note 7, at 5. ICCPR, supra note 7, at 173.

43 See Wojciech Kornacki, When Minority Groups Become "People" Under International Law, 25 N.Y. INT'L L. REV. 59, 71 (2012) ("Thanks to decolonization and the elimination of apartheid, hundreds of millions of people enjoy their fundamental right of self-determination today. Once self-determination was universally recognized, its assertion was no longer limited to colonial people." (footnote omitted)); Cynthia Dokas, The Duty to Warn in Aviation Law: A New Tort Theory in the Aftermath of Pan American Flight 103, 8 N.Y.L. SCH. J. HuM. RTS. 227, 239 (1990) ("Despite its absence in aviation law, self-determination has been universally recognized elsewhere.”).
} 
interfering in the internal affairs of other States and thereby adversely affecting the exercise of the right to self-determination." 44 Self-determination may seem identical to the other "self" phrases (self-sufficiency or self-reliance) at first glance; some scholars have even referred to them as nearly the same ideasusing the words almost interchangeably. ${ }^{45}$

But self-sufficiency actually encompasses a very different human rights protection. While self-sufficiency protects the people's rights to survive and even thrive in natural disasters or national emergencies through their preparation and their right to provide for their own everyday needs, the right to self-determination protects their broader rights to make fundamental life choices, ${ }^{46}$ such as what religion to join, ${ }^{47}$ what political party or system to elect, $^{48}$ what amount of money to invest or save, ${ }^{49}$ or what cultural norms to observe. ${ }^{50}$ For example, a right to self-sufficiency protects a person's right to store sufficient food, water, fuel, and medicine to prepare for an earthquake or flood without being subject to governmental regulations or seizures of such

44 Human Rights Instruments, Gen. Comm. No. 12, para. 6, HRI/GEN/1/Rev.9 (Vol. I) May 27, 2008, at http://tbinternet.ohchr.org/_layouts/treatybodyexternal/Download.aspx?symbolno=HRI\%2fGEN\%2f1\%2fRev. 9\%20(Vol.\%20I)\&Lang=en.

45 See Paul H. Brietzke \& Teresa L. Kline, The Law and Economics of Native American Casinos, 78 NEB. L. REV. 263, 328 (1999) ("Development is one such entitlement, an explicit part of the right to selfdetermination; tribal self-government has little meaning without a self-sufficiency."); Jon M. Van Dyke, The Political Status of the Native Hawaiian People, 17 YALE L. \& POL'Y REV. 95, 134 (1998) ("The programs are carefully designed to promote the self-governance and self-sufficiency of a native people, which is certainly an overriding goal of our nation, reinforced by emerging norms of international law. The right to selfdetermination is the most basic of human rights under federal and international law, and efforts to facilitate the exercise of this right are mandated by fundamental principles of human rights and human decency.").

46 Some scholars actually use this breadth to argue against the idea of granting a fundamental right of self-determination. R. Lansing, The Peace Negotiations, A Personal Narrative 97 (1921) (“[T]he phrase [self-determination] is simply loaded with dynamite. It will raise hopes which can never be realized.").

47 Kristen A. Carpenter, Limiting Principles and Empowering Practices in American Indian Religious Freedoms, 45 CONN. L. REV. 387, 397 (2012) ("Indian leaders have described the ability to practice their religion as critical to tribal 'self-determination." (citing Bear Lodge Multiple Use Ass'n v. Babbitt, 175 F.3d 814, 817 (10th Cir. 1999))).

48 See Louis B. Sohn, The New International Law: Protection of the Rights of Individuals Rather Than States, 32 AM. U. L. REV. 1, 48 (1982) (arguing that the right to self-determination includes "the right of individuals to select their own government"); Mari J. Matsuda, Looking to the Bottom: Critical Legal Studies and Reparations, 22 HARV. C.R.-C.L. L. REV. 323, 396 (1987) (stating that "self-determination for the Hawaiian people is guaranteed by international law" and citing the argument "that self-determination includes the right to negotiate with the United States for the return of the Hawaiian Islands").

49 See, e.g., Sandi B. Zellmer, Indian Lands As Critical Habitat for Indian Nations and Endangered Species: Tribal Survival and Sovereignty Come First, 43 S.D. L. REV. 381, 391-92 (1998) ("Utilization of trust lands to promote political and economic self-determination is an important attribute of the trust responsibility toward survival of tribes as unique cultural and governmental entities.").

50 E.g., ICESCR, supra note 7, at 5. 
property. A right to self-determination, on the other hand, protects a person's right to pursue a career as a doctor or lawyer instead of being forced by the government to be an accountant or engineer.

Additionally, the ICESCR recognizes the right to work, "which includes the right of everyone to the opportunity to gain his living by work which he freely chooses or accepts. ${ }^{, 52}$ As stated in an Economic and Social Council General Comment, "[t]he right to work is an individual right that belongs to each person and is at the same time a collective right." ${ }^{, 53}$ This right relates to a right to live self-sufficiently because working is a crucial part of selfreliance ${ }^{54}$ To live self-sufficiently, work is required as a basic component. But these two rights are distinguishable. A right to work is necessary to survive and provide for oneself and one's family, or even community. Self-sufficiency encompasses the right to work, but it extends beyond just a right to seek employment opportunities. A right to live self-sufficiently would entitle people to adequately prepare themselves for natural disasters (through food and fuel storage); also, a self-sufficient environment would at least provide opportunities to live independent of fossil fuels and "live off the land." Accordingly, the right to an environment of self-sufficiency, while similar to the right to work, is actually a different right that is independent from the right to work.

Perhaps the most similar right to self-sufficiency is "the right of everyone to an adequate standard of living for himself and his family, including adequate food, clothing and housing, and to the continuous improvement of living conditions. ${ }^{, 55}$ This right and the right to food ${ }^{56}$ seemingly go hand in hand. ${ }^{57}$

51 This right to work has also been recognized by several other international covenants and conventions. International Convention on the Elimination of All Forms of Racial Discrimination art. 5, Mar. 7, 1966, 660 U.N.T.S. 195; Convention on the Elimination of All Forms of Discrimination against Women art. 11, Sept. 3, 1981, 1249 U.N.T.S. 13; see generally International Convention on the Protection of the Rights of All Migrant Workers and Members of Their Families, July 1, 2003, 2220 U.N.T.S. 3.

52 ICESCR, supra note 7, at 6.

53 Economic and Social Council [ESCOR], The Right to Work, General Comment No. 18, q6, E/C.12/GC/18 (Nov. 24, 2005), available at http://tbinternet.ohchr.org/_layouts/treatybodyexternal/Download. aspx?symbolno=E $\% 2 \mathrm{fC} .12 \% 2 \mathrm{fGC} \% 2 \mathrm{f} 18 \&$ Lang=en.

54 See id. 14 ("Access to a first job constitutes an opportunity for economic self-reliance and in many cases a means to escape poverty.").

55 ICESCR, supra note 7, at 7 .

56 For more information on the right to food, see ESCOR, Substantive Issues Arising in the Implementation of the International Covenant on Economic, Social and Cultural Rights, General Comment No. 12, (May 12, 1999), available at http://tbinternet.ohchr.org/_layouts/treatybodyexternal/Download.aspx? symbolno=E\%2fC.12\%2f1999\%2f5\&Lang=en. 
Both lay essential groundwork in the fight against global poverty. Interestingly, the right to water, which seems at least as essential as the right to food, if not more, is not explicitly recognized in international law treaties. However, as recognized by the Committee on Economic, Social and Cultural Rights and scholars, the right to water must be acknowledged "as an essential corollary to the rights to life, health and food, and, it is of particular importance in many urban poverty areas." ${ }^{58}$ Actually, the right to water serves as a perfect example of a legal right that is emerging, like the right to an environment of self-sufficiency. ${ }^{59}$ But regardless of the right to water's recognition, or lack thereof, these types of rights - food, water, and living conditions - are all encompassed in the right to an adequate standard of living.

Some international law scholars house the right to an adequate standard of living, the right to food, and other similar rights under an umbrella of "habitat" rights. ${ }^{60}$ Such habitat rights are justified as rights for nearly the same reasons that bolster the need and ability to recognize the right to self-sufficiency. Why is it so fundamental for all people, no matter their race, religion, or class, to have sufficient food and an adequate residence? These are deemed fundamental rights for the same reasons that self-sufficiency is fundamental: survival. Just as the world has unreservedly and incontrovertibly recognized the fundamental need to absolve poverty by ensuring that people at least have the means to feed and shelter themselves on a daily basis, the international field should recognize the emerging right of self-sufficiency.

In the face of rising death tolls and economic weaknesses caused by global disasters, people worldwide should be able to prepare and protect themselves from dangers to come. International law should not permit any state

57 See Matthew Craven, The International Covenant on Economic, Social and Cultural Rights: A PERSPECTIVE ON ITS DeVElopment 287 (1995) ("There is no doubt that the right to an adequate standard of living, including the rights to food, housing, and clothing is of paramount importance not least because at minimum levels it represents a question of survival.").

58 James C. N. Paul \& Roktim Kaushik, Urban Poverty and the Right to A Decent Habitat As Established by International Human Rights Law, 63 RUTGERS L. REV. 905, 917 (2011) (footnote and citations omitted).

59 Gonzalo Aguilar Cavallo, The Human Right to Water and Sanitation: From Political Commitments to Customary Rule?, 3 No. 5 PACE INT'L L. ReV. OnLine Companion 136, 137 (2012) ("The legal existence of the human right to water and sanitation raises many objections. The lack of explicit recognition of this right in both the Universal Declaration of Human Rights and the International Covenant on Economic, Social and Cultural Rights is a strong argument in the debate concerning the existence of this right. In the last three decades, however, an increasing number of international and regional instruments have included clauses codifying aspects of the human right to water and sanitation. Without a doubt, such flourishing initiatives are a response to the growing water crisis.").

60 Paul, supra note 58, at 914-19. 
government to inhibit a person's right to prepare or live self-sufficiently. In fact, state governments should be required by law to enable self-sufficient environments by passing necessary legislation that would fuel this right, and the way to ensure the recognition of this global initiative, is through international recognition of the right to self-sufficiency.

\section{B. Social Movements Showing a Self-Sufficiency Trend}

In the past, not many people actively strove for the label "survivalist"; in fact, many associated such a term with extremism and anti-governmental minorities. ${ }^{61}$ But as natural disasters have hit with greater magnitude and terrorism has loomed with more frequency and peril, people worldwide are now treating the movement for self-sufficiency more seriously. ${ }^{62}$ Some have even argued that social movements with more specific names, like environmental justice or "green" infrastructure, are all actually a part of one large movement toward independence and self-reliance. ${ }^{63}$ No matter what label you put on this large-scale movement toward self-sufficiency, the general desire to obtain some level of self-reliance is on the move and growing fast. ${ }^{64}$ Furthermore, the people who are fueling this movement are normal people with normal goals of independence and financial stability - people do not have to be conspiracy theorists who believe the world is ending to actively support the self-sufficiency movement. ${ }^{65}$

This movement is not limited to developed countries like the United States. Actually, it is the less developed states that stand in the greatest need for such a

61 See Dan Gorenstein, The Self-Reliance Movement Goes Mainstream, MARKETPLACE (Feb. 12, 2013), http://www.marketplace.org/topics/life/weather-economy/self-reliance-movement-goes-mainstream ("“People are feeling anxiety about the economy, the threat of pandemics, you name it,' says Jim Rawles who runs the website SurvivalBlog. 'Preparedness has become big business.' Sales have only continued to grow at the Ready Store, an online firm that sells emergency preparedness supplies.”).

62 See id. (reporting that attendance at self-sufficiency trade shows, such as the Self Reliance Expo, has swelled "from several thousand a few years ago, to more than 10,000 these days").

63 Rick Fedrizzi, Self-Reliance Becomes a Movement, Huffington PosT (Feb. 9, 2012), http://www. huffingtonpost.com/rick-fedrizzi/selfreliance-becomes-a-mo_b_1263779.html ("Green building is not just about conserving resources, or recycling, or achieving Platinum certification. Rather, it's the universal ideals of independence and interdependence, of self-reliance and self-less collaboration that are at the core of our movement, and that have attracted such incredible support.").

64 See James George, Prepper Self-Reliance Movement May Be Larger Than the Tea Party, EXAMINER (Mar. 12, 2012), http://www.examiner.com/article/prepper-self-reliance-movement-may-be-larger-than-thetea-party-1.

65 Lee Bellinger, They're Making a Mockery of the Self Reliance Movement, INDEPENDENT LIVING NEwS, http://www.independentlivingnews.com/foods/community-updates/20364-theyre-making-a-mockeryof-the-self-reliance-movement.stml\#.VCBqnUuLFG4 (last visited Nov. 15, 2014). 
movement, and they are at least trying to participate. For example, scholars and news outlets alike see a need for more self-sufficiency in many African states, and they contend that people need to take a more active role to seek community self-reliance. $^{66}$ Even people within Africa know that selfsufficiency is the key to successful recovery and economic growth. ${ }^{67}$ The movement toward self-sufficiency is also happening at the national, governmental level in Africa. ${ }^{68}$ Although movements for self-sufficient governments and self-sufficient individuals reside in distinctly separate fields, the more self-sufficiency that a nation, community, or individual can achieve at each level, the less each entity will need to look outside itself for help and sustenance.

African nations are no strangers to social movements toward internal development. The self-sufficiency movement, which has only recently taken center-stage on the global front, stems from a historical movement toward progression of the developing states. Voluntary efforts to help developing states establish footholds in the global economy, or at least to help people in these nations meet their day-to-day needs, have existed for a long time. ${ }^{69}$ Through the years, scholars have continually studied successes and failures in national development to try and discern how to improve aid and recovery

66 Sammy Kum Buo, Africa's Lesson in Self-Reliance, INT'L Herald TrIB. (Apr. 23, 2013), http://www. nytimes.com/2013/04/23/opinion/global/africas-lesson-in-self-reliance.html ("No doubt there is growing recognition throughout Africa that predictable and lasting security can best be provided through internal good governance, good neighborly relations and national means."); Oliver Cann, Africa Must Become Self-Sufficient Says Zuma at Opening of World Economic Forum on Africa, World ECON. Forum (May 9, 2013), http://www.weforum.org/news/africa-must-become-self-sufficient-says-zuma-opening-world-economicforum-africa.

67 See Li Zhibiao, The Long Road to Economic Self-Reliance, ChINA DAILY (Sept. 13, 2013), http://africa.chinadaily.com.cn/weekly/2013-09/13/content_16967969.htm ("Of course Africa faces many challenges. The investment environment is not particularly stable, industrial support is relatively poor, and there is a severe shortage of management talent. The good news is that African countries are aware of these problems and have started to devote more time and effort to solving them.").

68 Former Prime Minister of the United Kingdom, Tony Blair, endorsed the movement to self-sufficiency in Africa by claiming that someday, adequate self-sufficiency policies and governments in Africa may render foreign aid largely obsolete. Tony Blair \& Kate Gross, From Dependency to Self-Sufficiency, STAN. Soc. INNOVATION REV. (Winter 2013), http://www.ssireview.org/articles/entry/from_dependency_to_ self_sufficiency. Far from advocating cruelty and unkindness in foreign nations who aid African states in this process, Blair and Kate Gross (former CEO of the Africa Governance Initiative (AGI)) actually were advocating the increasing capability and independence of the African states themselves. See id.

69 See generally Julie Fisher, NONGOVERnMENTs: NGOS AND THE POLITICAL DEVElopment of THE THIRD WORLD (1998). 
efforts $^{70}$ or to discern what risks are worth taking in the name of development. ${ }^{71}$

Finally, a new "sharing economy" has entered the playing field within the last decade. Essentially, the "sharing economy" is a movement happening primarily in the United States spear-headed by California attorney, Janelle Orsi, with a purpose to define legal challenges facing people in the United States who want to "go green." 72 In Orsi's book Practicing Law in the Sharing Economy, she essentially provides an instruction manual for attorneys whose practices revolve around helping people live self-sufficiently or, at a minimum, more environmentally friendly and energy efficient. ${ }^{73}$ This, albeit, domestic movement shows that a public desire for self-sufficient lifestyles and capabilities is gaining speed. But while this embodies a general goal for selfsufficiency, it lacks the specific application to developing and identifying an international human right that this article provides.

These scholarly analyses, various NGOs, social movements generally, and news reports regarding assistance for developing states have all set the stage for a new international human right of self-sufficiency. An additional spark to self-sufficiency's emergence as an international human right is the shift in focus to the individual from the state. ${ }^{74}$ Self-sufficiency even has its own social movement, uncurbed by oceans or social classes. Therefore, the time is politically and socially ripe for an international human right of self-sufficiency. Taking the ripeness of current world politics and social movements together with the textual support within pre-existing international treaties and covenants, leads to the next logical and natural step: recognizing an emerging human right to an environment of self-sufficiency.

70 See generally Human Rights And ThiRd World DEvelopment (Ved P. Nanda \& George Shepard eds., 1985); Maxwell O. Chibundu, Law in Development: On Tapping, Goulding and Serving Palm-Wine, 29 CASE W. RES. J. INT'L L. 167 (1997) (discussing the historical law and development area of legal academic study and research); Todd Johnston, The Role of International Equity in A Sustainable Future: The Continuing Problem of Third World Debt and Development, 6 BufF. ENVTL. L.J. 35 (1998).

71 See Yemi Osinbajo \& Olukonyisola Ajayi, Human Rights and Economic Development in Developing Countries, 28 INT'L LAW. 727, 727 (1994) ("This article examines the theory that economic development in third-world countries, especially through the vehicles of free market forces, direct foreign investment, and international business, necessarily involves compromises in human rights.”).

72 Janelle Orsi, Practicing Law in the Sharing Economy: Helping People Build Cooperatives, SOCIAL ENTERPRISE \& LOCAL SUSTAINABLE ECONOMIES 2-12 (2012).

73 Id. at $12-15,25-30$.

74 See Sohn, supra note 48, at 1 ("States have had to concede to ordinary human beings the status of subjects of international law, to concede that individuals are no longer mere objects, mere pawns in the hands of states."). 


\section{Why WE NEED TO ForMALly RECOGNIZE A RIGHT TO SELF-SUFFICIENCY}

On one ordinary spring morning a few years ago, a massive and unexpected tsunami hit the northeastern Honshu coast of Japan, causing destruction and long-term economic damage estimated at about \$309 billion ${ }^{75}$ and sparking several severe nuclear power plant scares. ${ }^{76}$ But the most lasting damage caused by the tsunami is the staggering death toll of more than 20,000 people of all ages and classes ${ }^{77}$ - the sea was truly "no respecter of persons." ${ }^{, 78}$ Why did so many have to die? The answer: both the government and its people, individually, were woefully unprepared for a natural disaster of such magnitude, despite the fact that the country is in a major tsunami hotspot. ${ }^{79}$

One school district, Kamaishi, managed to survive the disaster unscathed because of a government-initiated evacuation plan implemented in public

75 Keiko Ujikane, Japan Sees Quake Damage Bill of Up to $\$ 309$ Billion, Almost Four Katrinas, BLOOMBERG (Mar. 23, 2011), http://www.bloomberg.com/news/2011-03-23/japan-sees-quake-damage-bill-ofup-to-309-billion-almost-four-katrinas.html; see also Anita Greil, Shai Oster, \& Serena NG, Japan Damage Cost: $\$ 300$ Billion, WALl ST. J. (Mar. 22, 2011), http://online.wsj.com/article/SB10001424052748703858404 576214271676234818.html.

76 Bruce Parker, Why Did the 2011 Japan Tsunami Kill so Many People?, Huffington Post, Mar. 11, 2012, available at $\mathrm{http} / /$ www.huffingtonpost.com/bruce-parker/japan-tsunami_b_1335737.html.

77 U.N. OfF. FOR DisASTER RISK REDUCTION, 2011 GLOBAL ASSESSMENT REPORT ON DiSASTER RISK REDUCTION 5 (2011), available at http://www.preventionweb.net/english/hyogo/gar/2011/en/bgdocs/GAR2011/GAR2011_Report_Chapter1.pdf.

78 Acts 10:34 (King James); see DANIEl A. FARBER ET AL., DisASTER LAW AND Policy 204 (2d ed., 2010) ("Natural disaster supposedly does not discriminate; it putatively strikes everyone in its path, without regard to race, class, sex, age, or disability. In other words, 'poverty is hierarchic, smog is democratic."' (quoting Ulrich Beck, RisK SOCIETY: TOWARD A NEW MODERnity 36 (1986))). But see id. ("Though '[n]atural disasters such as hurricanes, earthquakes, and floods are sometimes viewed as great social equalizers' that 'strike unpredictably and at random, affecting black and white, rich and poor, sick and well alike,' harms from disasters 'are not visited randomly or equally in our society." (alteration in original) (emphasis added) (quoting CENTER For Progressive ReForm, An UnNATURAL DisAster: The AfTERMATH OF HURRICANE KATRINA 34 (2005))).

79 Parker, supra note 76. Parker lists several examples of how and why the Japanese government and people were not prepared: (1) The nuclear reactors had emergency diesel backup systems to take over when the electrical grid failed, but because they kept these diesel engines at ground level or in the basements below, the tsunami submerged them; (2) the Japanese had largely grown complacent about tsunami preparations because they had not seen a "deadly large tsunami since 1933"; (3) The Japanese thought the sea walls that line about forty percent of the coast would protect them, but these walls were not built high enough for the 2011 tsunami; (4) many of the labeled evacuation areas were not on high enough ground themselves, so many who evacuated to these areas died; and finally (5) "[t]he stories of what happened at many elementary and junior high schools sadly provide tragic insights into the lack of preparation." Id. Parker also discusses why the short time span between when submarine earthquakes are detected and when the tsunami hits, augments the importance of pre-disaster, nationwide preparedness; "it took only 29 minutes for the tsunami to reach the closest point on the Japanese coast" after the Japanese Meteorological Agency broadcasted the tsunami warning (and it took the agency three minutes after detecting the 9.0 magnitude earthquake to issue a warning). Id. 
schools. ${ }^{80}$ The Kamaishi School District, located in the Iwate Prefecture, which is right in the heart of the tsunami's devastating path, followed this plan called "Tsunami Tendenko," which roughly translated means "take care of yourself first, ${ }^{, 81}$ and every student in the school buildings at the time survived. ${ }^{82}$ This school district had been previously instructed in earthquake and tsunami survival tactics, and its story "provides a heartwarming illustration of the benefit of tsunami preparedness training." ${ }^{, 3}$ To develop tsunami preparedness training, "[s]ince 2005, the Kamaishi city government has invited disaster management education experts to offer advice," and such lessons included the Tendenko plan. ${ }^{84}$ These efforts by the local government to mandate selfsufficient disaster preparation and response saved roughly 2,900 children's lives, providing an exemplary scenario of why state governments should be required to take steps to encourage or at least allow for self-sufficient environments for their citizens. ${ }^{85}$

This example is highlighted here because of its magnitude; the deadly tsunami was caused by "the fifth largest [earthquake] in modern history." ${ }^{186}$ But there are many more natural disasters striking nations worldwide. Year 2011 was a record-breaking year for disasters, with a record ninety-nine federally declared major disasters in the United States alone. ${ }^{87}$ Although 2011 was a peak year for the disaster count, it will most likely not be an anomaly. ${ }^{88}$ These disasters come "in all shapes and sizes: wildfires, floods, blizzards,

\footnotetext{
$80 \quad I d$.

81 Donna Tam, Experts Highlight Education's Role in Tsunami Preparedness, TIMES STANDARD (Mar. 11, 2012), http://www.times-standard.com/ci_20150654/experts-highlight-educations-role-tsunamipreparedness.

82 Parker, supra note 76.

83 Id.

84 Justin Sharpe, Teaching of Tendenko Saved Lives of School Children in Japan, EFFECTIVE EDUC. FOR DiSASTER RISK REDUCTION-LEARNING MATTERS (April 17, 2011), http://www.edu4drr.org/profiles/blogs/ teaching-of-tendenko-saved; see also Tam, supra note 81 ("For two years, the students at Kamaishi Higashi Junior High School, located in a coastal city in the Iwate Prefecture, were taught tsunami preparedness with lessons centered around the idea of tendenko: don't assume what you've been told is necessarily the way it's going to be, and do as much as you can as fast as you can.").

85 See Sharpe, supra note 84.

86 Parker, supra note 76.

87 Natural Disasters: Counting the Cost of Calamities, ECONOMIST (Jan. 14, 2012), http://www. economist.com/node/21542755.

88 In the past thirty-three years, the United States has sustained 170 weather-related natural disasters, in which damages either reached or exceeded \$1 billion. Billion Dollar U.S. Weather Disasters, NAT'L Climate DATA CENTER, http://www.ncdc.noaa.gov/billions/events (last visited Nov. 15, 2014). Of these 170 disasters, 95 have occurred from 2000 to 2013, and of those, 75 have occurred from 2005 to 2013. Id. Clearly in recent years, disasters are increasing both in frequency and in magnitude.
} 
hurricanes, ... earthquakes," and tsunamis. ${ }^{89}$ Just within the last few months, the natural disaster death toll has risen, which is at least in part due to a lack of adequate preparation around the globe; causes of this death toll rise include: a 7.7 magnitude earthquake in Pakistan killing at least 330 people, ${ }^{90}$ heavy rains and flooding in China's northwest Gansu Province killing 8 people and destroying or damaging 4740 acres of farmland and at least 2690 homes, $^{91}$ annual heavy flooding in Cambodia killing at least 104 people so far this year and 250 in 2011, ${ }^{92}$ and several others. ${ }^{93}$ And even though 2012 was a relatively mild year as far as global disasters go, ${ }^{94}$ natural disasters that year still "inflict[ed] billions of dollars in property and infrastructural damage" and killed thousands of people. ${ }^{95}$ Overall, natural disasters are on the rise, and they are becoming more and more costly. ${ }^{96}$

89 Justin Pidot, Deconstructing Disaster, 2013 BYU L. REV. 213, 214-15 (2013).

90 Death Toll Rises to 330 in Pakistan Quake, CNN (Sept. 25, 2013), http://www.cnn.com/2013/09/25/ world/asia/pakistan-earthquake/; see also Jubail Muhammad Hafeez Ur Rahman, Readers' Post, Pakistan Unprepared for Natural Disasters, SAUDI GAZETTE (Sept. 29, 2013), http://www.saudigazette.com.sa/index. $\mathrm{cfm}$ ?method=home.regcon\&contentid=20130929181919 (arguing that Pakistan's disaster management experts failed to prepare for this disaster despite their knowledge that they are in an earthquake-afflicted zone and the devastating earthquake that took place in northern Pakistan in 2005); New Earthquake Strikes Hard-Hit Pakistan, CNN (Sept. 28, 2013), http://www.cnn.com/2013/09/28/world/asia/pakistan-earthquake/index.html (discussing the 7.7 magnitude earthquake in Rahman's article and adding an additional report of a 6.8 magnitude earthquake that struck the nation just four days later).

91 Jinghui Chen, Deadly Flooding Strikes Northwest China's Quake-Hit Province, EPOCH TIMES (Sept. 19, 2013), http://www.theepochtimes.com/n3/292416-deadly-flooding-strikes-northwest-chinas-quake-hitprovince/ (translated by Euly Luo; written in English by Christine Ford).

92 Phnom Penh, Floods in Cambodia Kill More than 100, Associated Press (Oct. 9, 2013), http:// bigstory.ap.org/article/floods-cambodia-kill-more-100 ("Disaster management committee spokesman Keo Vy said Wednesday that floods in the past several weeks have affected some 1.5 million people in 17 of the country's 24 provinces.").

93 Deadly Natural Disasters, RECENT NATURAL DiSASTERS, http://www.disaster-report.com/search/ label/Deadly\%20Natural\%20Disasters (last visited Nov. 15, 2014).

94 The year 2012's major disaster declaration count of 47 total pales in comparison to 2011's recordbreaking 99. Disaster Declarations by Year, FEMA, http://www.fema.gov/disasters/grid/year (last visited Nov. 15, 2014). But even still, there were enough to cause widespread concerns; an Outdoor Life contributor opined that "2012 will go down in the history books as having some powerful and even record breaking natural disasters." Tim MacWelch, The 20 Worst Natural Disasters of 2012, OUTDOOR LiFE, http://www.outdoorlife. com/photos/gallery/survival/2012/12/20-worst-natural-disasters-2012 (last visited Nov. 15, 2014).

95 Worst Disasters of 2012 (PHOTOS), HUFFINGTON POST (Dec. 28, 2012), http://www.huffingtonpost. com/2012/12/28/worst-natural-disasters-of-2012_n_2349311.html\#slide=1898048 (highlighting the year's biggest natural disasters including: Hurricane Sandy — which ravaged New England, killing at least 125 people and inflicting $\$ 62$ billion in damages; wildfires across the western United States - which "burned 30 percent more area than in an average year by September, 'with nearly two months still to go in the fire season"'; and Typhoon Bopha in the Philippines - which claimed more than 1,000 lives and left many homeless). For more data on future damages predicted from wildfires, see U.S. Wildfires: Burn Area Expected to Double by 2050, HufFINGTON POST (Dec. 17, 2012), http://www.huffingtonpost.com/2012/12/17/us-wildfires-burn-area_n_ 
Due to this rise in natural disasters and their associated costs, widespread disaster preparedness and the general ability to survive self-sufficiently is becoming increasingly important. ${ }^{97}$ Programs to help people afflicted by disasters are already forming, but these programs only go into effect in the disaster's aftermath ${ }^{98}$ Charity organizations are coming together and forming NGOs to raise funds to fight poverty generally and to help local leaders in developing nations prepare for "natural and other man-made disasters,... respond to the needs of their communities[,] and build their self-sufficiency." 99

The assistance and preparation in the private sector is certainly good news. But people worldwide have a right to more than just optional charities and programs that could disband at any time. Even with a heightened focus on disaster preparation in the aftermath of global natural disasters, most people are still unprepared because of the general attitude that there will be time later to prepare. ${ }^{100}$ Each person deserves and needs a right to live in a governmentmandated environment where they can thrive self-sufficiently, if they so choose.

Finally, even if disasters did not present such an imminent threat to many societies worldwide, it just makes sense for people to live in a reasonably self-

2315110.html. This Wildfires article suggests that based on computer modeling and satellite observations the total area burned by wildfires in the United States will probably double by 2050 . Id.

96 "From 1990 to 2007, worldwide mortality risk from floods, for example, increased by 13 percent, and the economic risk posed by floods increased by 33 percent." FARBER, supra note 78, at 9; see also Disaster Declarations by Year, FEMA, http://www.fema.gov/disasters/grid/year (last visited Nov. 15, 2014) (charting major disaster declarations over the years and showing that 2013's count (52) has already surpassed the total for 2012 (47)).

97 For example, Auckland, New Zealand's Civil Defense controller expressed concerns about the total lack of preparation for a volcanic eruption among Aucklanders - with only about one in ten people prepared for most eventualities, Auckland is the least prepared city in New Zealand. Simon Day, Auckland the Most Unprepared for Disaster, STUFF.CO.NZ (Sept. 27, 2013), http://www.stuff.co.nz/national/9219092/Aucklandthe-most-unprepared-for-disaster. Yet the volcanic field in Auckland is "the most densely populated field of its type in the world." Id. In fact, "[f]ifty-six volcanoes have been identified in the field." Id.

98 See, e.g., Genevieve Belmaker, Fund to Help Sandy Victims Seeks \$12 Million, Epoch TimES (Oct. 8, 2013), http://www.theepochtimes.com/n3/311800-fund-to-help-sandy-victims-seeks-12-million/?photo=2 (stating that the Sandy Unmet Needs Rountable group is working to meet "extreme unmet needs," such as those "preventing self-sufficiency").

99 Muna Wehbe, Fund the Front Line-The Stars Foundation: Money Where It's Needed, THE GUARDIAN, http://www.theguardian.com/fund-the-front-line/the-stars-foundation-money-where-its-needed (last visited Nov. 15, 2014).

100 See Tanya Lewis, Why People Don't Learn from Natural Disasters, Live SCIENCE (July 9, 2013), http://www.livescience.com/38036-why-people-unprepared-for-natural-disasters.html; Mimi Hall, Most People Unprepared for Disaster, USA TODAY (Dec. 18, 2006), http://usatoday30.usatoday.com/news/nation/ 2006-12-17-prepare_x.htm. 
sufficient manner, so long as people do not infringe on the rights of others. Just as the general populace tends to be risk averse in the context of purchasing life insurance just in case the worst should happen, ${ }^{101}$ on average, if people are able to look past the immediate concerns of day-to-day planning, they will likely try to prepare to live self-sufficiently, should the need arise.

Thus, self-sufficiency should be preserved by state governments because it is an inherently fundamental and inalienable right. A right to a self-sufficient environment fits among the select "freedoms [that] should exist among all peoples in all times, whether in highly complex societies or in simple family groups." 102 To determine whether a right belongs in this elite group of fundamental rights, one scholar coined a "litmus test" in which he posed the question of whether society would benefit as a whole if "everyone employed that right fully." ${ }^{\prime 103}$ If everyone in the world exercised a right to live selfsufficiently, this global behavior would be the means of solving many international problems, such as poverty, hunger, debilitating devastation in the aftermath of natural disasters, and general dependency on foreign aid.

\section{CONCLUSION}

Self-sufficiency is emerging as an international human right. Existing allusions to self-sufficiency in both recognized international rights and current social movements, highlight the global value of self-sufficiency. Citizens internationally need a right to self-sufficiency for two primary reasons: (1) the rise in natural disasters and in the costs they impose on societies globally show the vitality of self-sufficient living and preparation, and (2) principles of common sense and rationality naturally point to self-sufficient lifestyle habits

101 FARBER, supra note 78, at 249 ("People are often risk averse - that is, they prefer not to gamble. For instance, they may strongly prefer a sure thing of losing $\$ 1,000$ in the form of paying an insurance premium rather than take a 1 percent chance of losing $\$ 100,000$. Yet, if you do the arithmetic, you will see that in expected value terms, the two are equivalent. $(1 \mathrm{X} 1,000=.01 \mathrm{X} 100,000) . ")$.

102 A. Scott Loveless, The Forgotten Founding Document: Considering the Ends of the Law, 27 BYU J. PUB. L. 365, 385 (2013) (arguing that the right to homosexual marriage is not a fundamental right within the spirit (Declaration of Independence) and letter (U.S. Constitution) of United States law).

103 See id,; see also Kelly A. Spencer, Sex Offenders and the City: Ban Orders, Freedom of Movement, and Doe v. City of Lafayette, 36 U.C. DAvis L. REV. 297, 304 (2002) (citing San Antonio Indep. Sch. Dist. v. Rodriguez, 411 U.S. 1, 33-34 (1973); Palko v. Connecticut, 302 U.S. 319, 325 (1937); Snyder v. Massachusetts, 291 U.S. 97, 105 (1934) (noting that one way a right can be deemed fundamental in the United States, if it is not explicitly stated in the Constitution, is if the U.S. Supreme Court decides that such right is "inherent in the concept of ordered liberty")). Although the proclamation of this logic originated in the United States, the idea that fundamental rights are those which are implicit in the concept of ordered liberty is a theory that can and often is applied globally. 
as the best way to live and conclude that self-sufficiency is a fundamental right because such practices remove reliance on outside aid for sustenance.

The international community should recognize the right to live in an environment where self-sufficiency is at least possible and even publicly encouraged with governmental incentives. People need this right to protect themselves from potential natural disasters or personal crises, and to sustain themselves even in good times for their own independent security. Due to this need, the international community should agree to prohibit state governments from preventing the establishment of a self-sufficient life for individual citizens and should, furthermore, expect states to create an environment where self-sufficiency can flourish through legislation and other methods of public encouragement. 